\title{
Characteristics of an endophytic microbial consortium and its impact on rhizosphere microbiota of barley
}

\author{
Dagnija Vecstaudža' ${ }^{1}$, Mãris Seṇkovs² $^{2}$, Vizma Nikolajevaa ${ }^{2 *}$, Olga Mutere ${ }^{1}$ \\ ${ }^{1}$ Institute of Microbiology and Biotechnology, University of Latvia, Jelgavas 1, Riga LV-1004, Latvia \\ ${ }^{2}$ Faculty of Biology, University of Latvia, Jelgavas 1, Riga LV-1004, Latvia \\ ${ }^{\star}$ Corresponding author, E-mail: vizma.nikolajeva@lu.lv
}

\begin{abstract}
Biological fertilizers are being developed on the basis of plant growth promoting microorganisms isolated from the plant rhizosphere, phyllosphere and endosphere. The aim of this study was to determine influence of a consortium of plant endophytes on rhizosphere microbiota in a greenhouse vegetation experiment with barley. Fifty-five bacterial and fungal strains were isolated from leaves, stems and roots of oilseed rape and barley. Twentty five of them did not inhibit seed germination. Most of them belonged to the genera Serratia, Enterobacter, Brevibacillus and Pseudomonas. Individual isolates demonstrated phosphate solubilization ability, nitrification potential and urease activity. Impact of the multi-strain microbial consortium on cultivable microbiota of rhizosphere was estimated in a 19-day greenhouse experiment with barley. Concentration of phosphate solubilizing and cellulolytic microorganisms in the rhizosphere was below the detection limit. The consortium increased the total number of bacterial colony-forming units but did not affect the number of actinobacterial and fungal colony-forming units. Interactions between species in the multi-strain consortium and between introduced and indigenous populations are discussed.
\end{abstract}

Key words: endophyte, microbial consortium, nitrification, phosphate solubilization, rhizosphere, urease. Abbreviations: CFU, colony-forming units; IAA, indole-3-acetic acid; P, phosphate; PSI, phosphate solubilising index.

\section{Introduction}

Biological fertilizers contain microorganisms and improve plant growth and development (Herrmann, Lesueur 2013). Microorganisms can be isolated from soil and the plant rhizosphere (Bhardwaj, Ansari 2014). Incorporation of mycorrhizal fungi, phyllosphere microorganisms and endophytes into biofertilizer formulations has attracted great attention in development of alternative fertilizers for improving plant growth and soil quality (Schulz, Boyle 2006).

Endophytes originate from microbial communities of the rhizosphere and phylloplane (Hallmann et al. 1997). Studies have shown that endophytic cultivable strains isolated from surface sterilized roots, stems or leaves have promising plant growth-promoting traits that can be introduced in biofertilizers (Qin et al. 2015). Plantassociated bacteria can be screened in vitro for multiple plant growth-promoting activities like production of indole-3-acetic acid (IAA), ammonia, siderophore and phosphate (P) solubilization (Ahmad et al. 2008).

There is evidence that the soil microorganisms respond differently to inputs of inorganic and organic fertilizers, leading to the change of bacterial and fungal composition (Wang et al.2017). Response of higher plants to introduction of beneficial microorganisms into the rhizosphere was reported as growth promoting. In particular, stable colonization ability as well as regulation of the microbiota in the rhizosphere, with inhibition of Fusarium solani, was shown in the pot experiments with Streptomyces spp. and tomato plants (He et al. 2015). Ma et al. (2017) reported a $37 \%$ decrease of root knot nematode index and growth stimulating effect in tomato plants after inoculation by Streptomyces spp. Representatives of Azospirillum, Bacillus, Enterobacter, Klebsiella, and Pseudomonas spp. are considered to contribute plant growth by production of osmolytes, polysaccharides and phytohormones, by action of specific enzymes, stress adaptation abilities and positive interactions with other microbial communities (Nadeem et al. 2016).

A study of endophytic mycobiota in grasses in terms of richness and distribution reported 77 and 79 fungal endophyte isolates from leaves and roots of Holcus lanatus, and only 22 were common for both organs (Márquez et al. 2010). It was shown that plant species-specific selection of endophytes is driven by functional rather than phylogenetic traits (Wemheuer et al. 2017). Thus, efficiency of developed biofertilizers depends on the plant species, origin and physiological characteristics of microorganisms, as well as on a broad spectrum of environmental factors.

Many biofertilizers consist of one microbial strain. In such a case, all the effects can be easily attributed to the 
particular species. Coinoculation would combine different mechanisms and effects. Combination of strains and species can produce additive or synergic effect (Marimuthu et al. 2002), but also can cause competitive processes (Probanza et al. 2002) that reduce or prevent growth enhancement and, ultimately, the impact can be unpredictable (reviewed in Trabelsi, Mhamdi 2013). Plant growth might not necessarily be affected by direct action but may be related to positive and negative interactions between introduced and indigenous microbial populations. There are too many unknowns to assess the health of the soil and soil microbial community in each specific case (reviewed in Das, Varma 2011).

The aim of this study was investigation of influence of a consortium of plant endophytes on rhizosphere microbiota. Endophytic microorganisms were isolated, identified and characterized with emphasis on nitrification potential, urease activity and P solubilizing activity. Previously, it was found that the created consortium did not have significant effect on shoot and root length of barley (Vecstaudza et al. 2017). In this study, influence of a microbial consortium on rhizosphere microbiota was estimated in a greenhouse vegetation experiment with barley.

\section{Materials and methods}

\section{Isolation and identification of plant endophytes}

Endophytic microorganisms were isolated from oilseed rape (Brassica napus L.) and barley (Hordeum vulgare L.) which were grown in Dobele municipality (Latvia). Plants were grown for 75 days in loamy soil. Microorganisms were isolated from leaves, stems and roots of the plants. Samples were washed in distilled water three times and surfacesterilized by dipping in $70 \%$ ethanol for $30 \mathrm{~s}$ followed by repeated rinsing with sterile water. Sterile $0.02 \mathrm{M}$ potassium phosphate buffer ( $\mathrm{pH}$ 7.4) was added to the samples, which were then ground (Zinniel et al. 2002) and added to $50 \mathrm{~mL}$ tubes with malt extract broth (Biofile, Italy) or nutrient broth (Bio-Rad, France). The volume of the medium was 10 times larger than the sample volume. Samples were incubated at $37^{\circ} \mathrm{C}$ and $100 \mathrm{rpm}$ for $24 \mathrm{~h}$. Decimal dilutions of samples were prepared and spread plated on nutrient agar (Scharlab, Spain) plates for isolation of bacteria or on Malt extract agar (Lab M, UK) for isolation of fungi. Nutrient agar plates were incubated at $37^{\circ} \mathrm{C}$ for $24 \mathrm{~h}$ and Malt extract agar plates were incubated at $24^{\circ} \mathrm{C}$ for 7 days. After incubation morphologically different colonies were plated separately. Isolates were preserved in $4{ }^{\circ} \mathrm{C}$ and replated monthly.

Microorganisms were identified using microscopic appearance, Gram staining, the oxidase test, $\mathrm{BD} \mathrm{BBL}^{\mathrm{m}}$ Crystal $^{\mathrm{Tm}}$ Identification Systems (Becton \& Dickinson, USA) for bacteria and the identification system API ${ }^{\circ}$ ID 32C (Biomerieux, France) for yeasts. Genera of filamentous fungi were determined according to micromorphological features (Kiffer, Morelet 2000).

\section{Characterization of the activity of plant endophytes}

Isolated microorganisms were selected for development of a biofertilizer by testing their influence on seed germination. Suspensions of microorganisms (a loopful of a fresh colony of isolate mixed with $50 \mathrm{~mL}$ of sterile water) was added to seeds of radish, alfalfa, cress and barley to liquid, which minimally covered the seeds. Three seeds from every species separately in three repetitions (nine seeds in total) were incubated in $10 \mathrm{~mL}$ containers for 7 days at room temperature in the dark. Isolates that did not inhibit germination in comparison with control without microorganisms, were selected for further testing (data not shown).

Ability of microorganisms to affect plant growth was tested by measuring their phosphate solubilizing index (PSI) on agar medium (Promwee et al. 2014) and their nitrification potential and urease activity (American Public Health Association 1992). Isolate suspensions were incubated in reaction mixture for $48 \mathrm{~h}$ at $37^{\circ} \mathrm{C}$ for determination of nitrification potential and urease activity. Protein concentration of microbial suspensions was measured (Bradford 1976) to characterize the concentration of microorganisms. Specific nitrification potential and urease activity were expressed in relative units by dividing the concentration of $\mathrm{N}^{-\mathrm{NH}_{4}}{ }^{+}$in isolate suspensions with optical density of suspensions obtained in the Bradford protein assay.

\section{Testing of consortium impact on rhizosphere microbiota}

Twenty-five isolates which were obtained from all studied organs of rape and barley, and did not inhibit seed germination, were selected for the vegetation experiment and mixed together. The vegetation experiment was conducted in $60 \mathrm{~mL}$ volume seed trays with $50 \mathrm{~g}$ of loamy soil and barley cv. 'Austris' in a greenhouse for 19 days as described previously (Vecstaudza et al. 2017). One mL of each microorganism isolate was mixed with sterile water to achieve $2.7 \times 10^{10}$ colony-forming units (CFU) $\mathrm{mL}^{-1}$ for bacteria and $1.2 \times 10^{7} \mathrm{CFU} \mathrm{mL} \mathrm{m}^{-1}$ for fungi. The microbial suspension was mixed with the soil. The experiment was done in triplicate. At the end of the experiment, average samples of rhizosphere soil consisting of three subsamples were collected. Decimal dilutions of average samples were prepared and plated on five media: nutrient agar (Scharlab, Spain) for total number of cultivable bacteria, Rose Bengal agar with chloramphenicol (Biolife, Italy) for fungi, NBRIP agar (glucose $10 \mathrm{~g} \mathrm{~L}^{-1}, \mathrm{MgCl}_{2} \times 6 \mathrm{H}_{2} \mathrm{O} 5 \mathrm{~g} \mathrm{~L}^{-1}, \mathrm{Ca}_{3}\left(\mathrm{PO}_{4}\right)_{2} 5 \mathrm{~g}$ $\mathrm{L}^{-1}, \mathrm{MgSO}_{4} \times 7 \mathrm{H}_{2} \mathrm{O} 0.25 \mathrm{~g} \mathrm{~L}^{-1}, \mathrm{KCl} 0.2 \mathrm{~g} \mathrm{~L}^{-1},\left(\mathrm{NH}_{4}\right)_{2} \mathrm{SO}_{4} 0.1 \mathrm{~g}$ $\mathrm{L}^{-1}$; agar $15 \mathrm{~g} \mathrm{~L}^{-1}$ ) (Nautiyal 1999) for P solubilising bacteria, Actinomycete isolation agar (Sigma-Aldrich, Germany) for actinobacteria and CMC agar $\left(\mathrm{KH}_{2} \mathrm{PO}_{4} 1.0 \mathrm{~g} \mathrm{~L}^{-1}, \mathrm{MgSO}_{4}\right.$ $\times 7 \mathrm{H}_{2} \mathrm{O} 0.5 \mathrm{~g} \mathrm{~L}^{-1}, \mathrm{NaCl} 0.5 \mathrm{~g} \mathrm{~L}^{-1}, \mathrm{FeSO}_{4} \times 7 \mathrm{H}_{2} \mathrm{O} 0.01 \mathrm{~g} \mathrm{~L}^{-1}$, $\mathrm{MnSO}_{4} \times \mathrm{H}_{2} \mathrm{O} 0.01 \mathrm{~g} \mathrm{~L}^{-1}, \mathrm{NH}_{4} \mathrm{NO}_{3} 0.3 \mathrm{~g} \mathrm{~L}^{-1}$, carboxymethyl cellulose sodium salt $10.0 \mathrm{~g} \mathrm{~L}^{-1}$, agar $12.0 \mathrm{~g} \mathrm{~L}^{-1}$ ) (Samira et al. 2011) for cellulolytic microorganisms. Nutrient agar and Actinomycete agar plates were incubated at $37^{\circ} \mathrm{C}$ for $24 \mathrm{~h}$, 
Rose Bengal agar at $24^{\circ} \mathrm{C}$ for $48 \mathrm{~h}, \mathrm{CMC}$ plates at $37^{\circ} \mathrm{C}$ for 5 days and NBRIP at $28{ }^{\circ} \mathrm{C}$ for two weeks. The number of CFU was determined at the end of an incubation period. Cellulolytic activity was determined by the Teather and Wood (1982) method.

\section{Statistical analysis}

Microsoft Excel was used for calculating average values and standard deviations. Program R was used for data statistical processing with a level of significance 0.05 .

\section{Results and discussion}

Fifty-five isolates were obtained from plant material and tested for their effect on plant seed germination. Germination of radish, alfalfa, cress and barley was estimated in suspensions with the isolates. Twenty-five isolates did not inhibit plant germination after 7-day incubation. These microorganisms were (number of strains shown in brackets): bacteria Brevibacillus brevis (3), Enterobacter cancerogenus (1), Enterobacter cloacae (1), Enterobacter sp. (2), Kytococcus sedentarius (1), Lactococcus lactis ssp. hordniae (1), Micrococcus luteus (1), Pantoea agglomerans (1), Pseudomonas putida (2), Pseudomonas sp. (1), Serratia liquefaciens (5) and Stenotrophomonas maltophilia (2), filamentous fungi Mucor sp. (2) and yeasts Cutaneotrichosporon mucoides (1) and Wickerhamomyces anomalus (1). Many isolates of the same species differed in physiological characteristics and thus belonged to different biotypes. These 25 isolates were further tested as a consortium.

Many microorganisms produce phytotoxic volatile and/or soluble compounds and compete with seeds for oxygen and other compounds, and as a result, inhibit seed germination (Sarlistyaningsih et al. 1996; Weise et al. 2013). Other microorganisms do not inhibit germination and many of them are known to promote plant growth. In our study, bacteria and fungi that did not inhibit germination had such plant growth affecting properties like solubilization of inorganic insoluble $\mathrm{P}$ and nitrification and urease activity.

All isolates were able to form colonies on NBRIP agar, while only 11 isolates from six genera (Enterobacter, Lactococcus, Pantoea, Serratia, Cutaneotrichosporon and Wickerhamomyces) showed clear lysis zones (Fig. 1). Two isolates had the highest PSI, i.e. Lactococcus lactis ssp. hordniae and Pantoea agglomerans. Phosphorus is one of the major growth-limiting nutrient elements for plants in any ecosystem although it is abundant in soils in different forms of usually insoluble inorganic P (Gyaneshwar et al. 2002). The ability to solubilize $P$ was characterized using PSI. Formation of halo zones around colonies or tricalcium $\mathrm{P}$ is commonly used for screening of P-solubilizing microorganisms. It has been shown that PSI is likely not a reliable indicator for determining the ability of microorganisms to solubilize P. Microorganisms that do not produce lysis zone on agar plates often can solubilize $\mathrm{P}$ in liquid medium (Nautiyal 1999). Also Spagnoletti et al. (2017) found differences between solid and liquid medium in a study with dark septate endophytic fungi. Chen et al. (2014) showed that a reliable indicator for microorganism ability to solubilise $\mathrm{P}$ is the colony diameter and size of cells. Their observations explain why the $\mathrm{P}$ concentration in liquid broth does not always correlate with PSI or diameter of the lysis zone. Isolates with small cells form relatively small colonies, but are able to solubilize a significant amount of $\mathrm{P}$ in liquid broth due to a high cell surface area-volume ratio. The ability to solubilize $\mathrm{P}$ is generally associated with production of organic acids, which results in the acidification of media (Vyas, Gulati 2009). Bacteria from the genera Acinetobacter, Burkholderia, Enterobacter, Exiguobacterium, Pantoea, Pseudomonas etc. have been

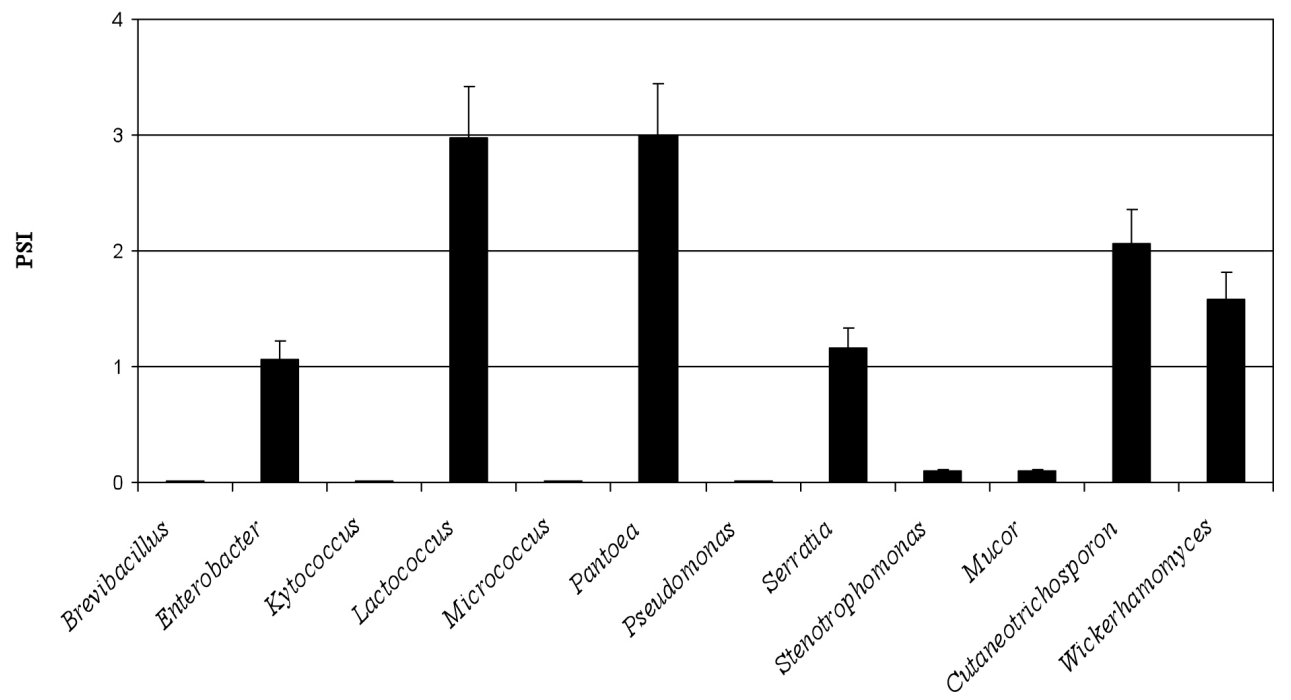

Fig. 1. Mean PSI of microbial genera in NBRIP medium. Values are mean \pm standard deviation of four replicates from each strain. 


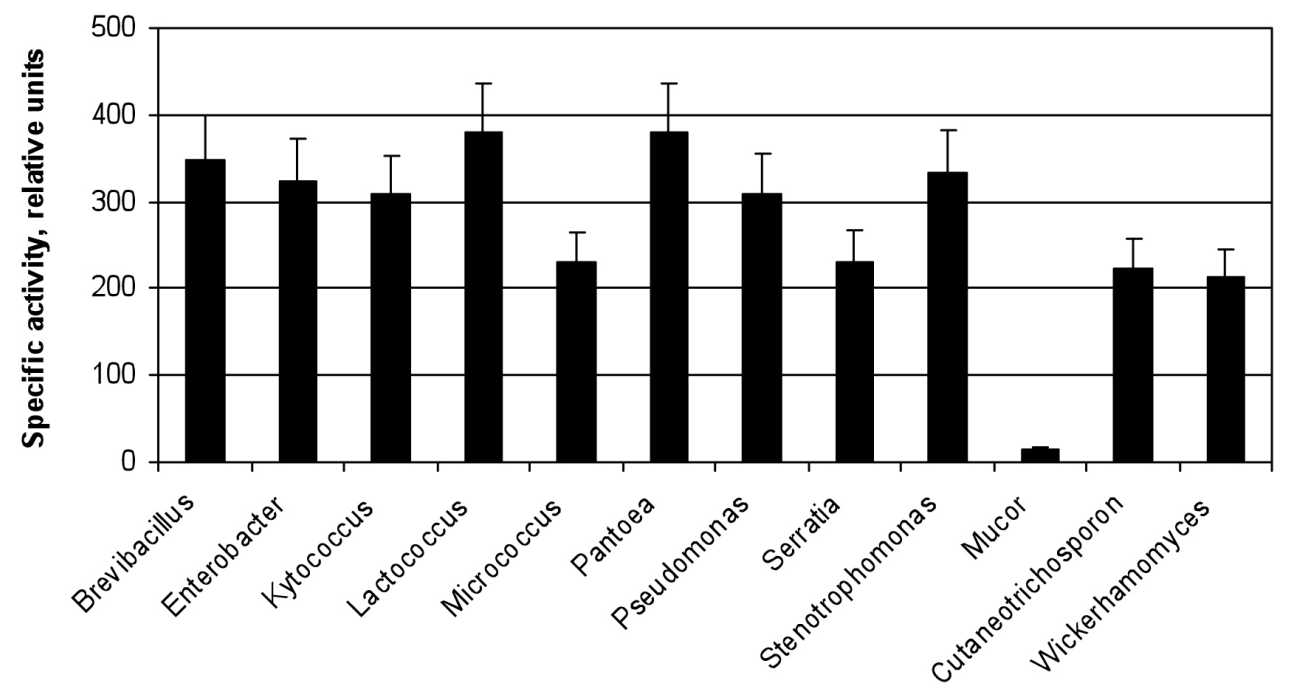

Fig. 2. Mean specific activity of nitrification potential of microbial genera. Suspensions were incubated in reaction mixture for $48 \mathrm{~h}$ at $37^{\circ} \mathrm{C}$. Values are mean \pm standard deviation of four replicates from each strain.

recognized as active P-solubilizers (Collavino et al. 2010; Oteino et al. 2015). Lactococcus and Pantoea as well as Enterobacter, Serratia and yeasts isolated in this study, showed relatively high P-solubilization ability. However, solubilization of inorganic $\mathrm{P}$ in vitro is not always associated with promotion of plant growth (Collavino et al. 2010). Furthermore, this feature may be advantageous to plants only under deficiency of bioavailable or dissolved P.

Nitrification potential (Fig. 2) varied in microbial suspensions from 29.2 relative units for Mucor spp. to 379.7 for Lactococcus lactis ssp. hordniae. All isolates showed urease activity (Fig. 3). Specific activity of urease varied from 29.3 units for Enterobacter spp. to 288.0 units for Mucor spp. In our experiments, nitrification activity characterized the ability of the isolates to perform heterotrophic nitrification. Nitrification was observed for all isolates, with the exception of one Mucor sp., while both our Mucor isolates showed high urease activity. Mucor spp. can produce urease and other extracellular enzymes (Thompson, Eribo 1984). Ureolytic species (from genera Sporosarcina, Bacillus, Lysinibacillus, Arthrobacter, Brevibacterium etc.) are widely distributed in soil (Burbank et al. 2012). It was previously found that the consortium used in the present study significantly diminished urease activity in the soil and did not have any impact on the nitrification potential of soil (Vecstaudza et al. 2017). It should be noted that urease and nitrification are not always considered as plant growth-promoting. Urea is a widely used nitrogen fertilizer but in most soils it is rapidly converted to carbon dioxide and ammonia and volatilized (Choi et al.2007). Urease also contributes to the production of nitrous oxide and dinitrogen gas and leaching of soil nitrate, and leads to reduced availability of nitrogen to

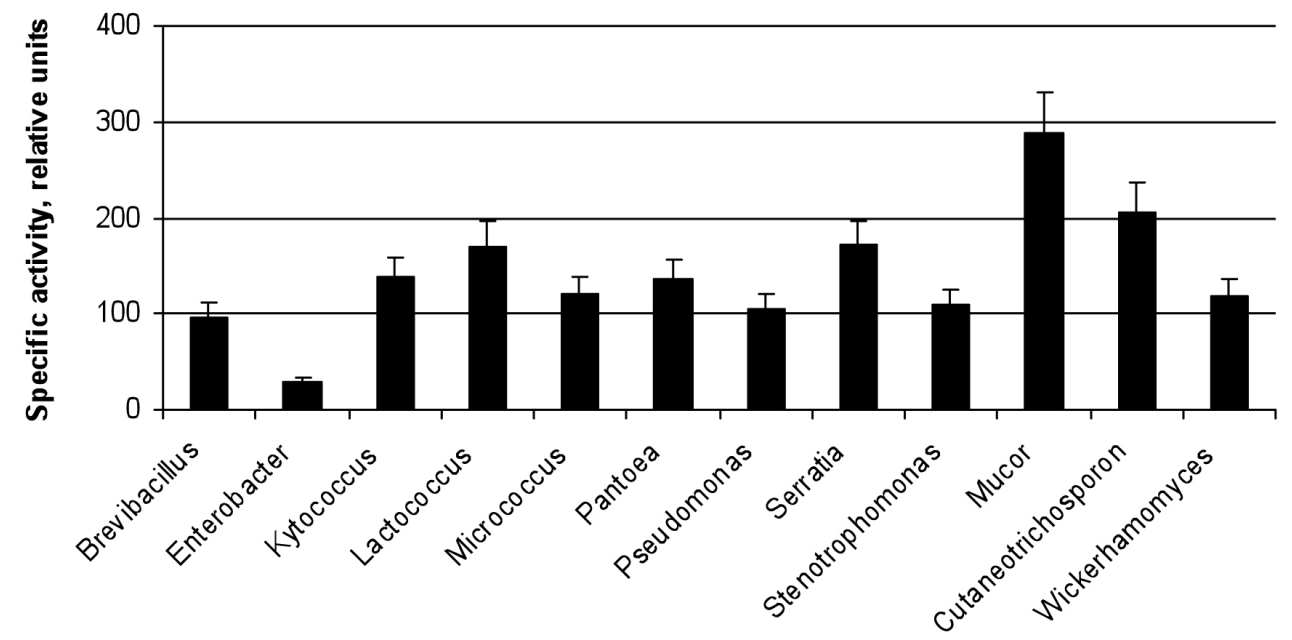

Fig. 3. Mean specific activity of urease $\left(\mathrm{N}_{-} \mathrm{NH}_{4}^{+} \mathrm{mg} \mathrm{L}^{-1} \mathrm{OD}_{620}\right.$ protein $\left.{ }^{-1}\right)$ of microbial genera. $48 \mathrm{~h}$ incubation was carried out in reaction mixture at $37^{\circ} \mathrm{C}$. Values are mean \pm standard deviation of four replicates from each strain. 


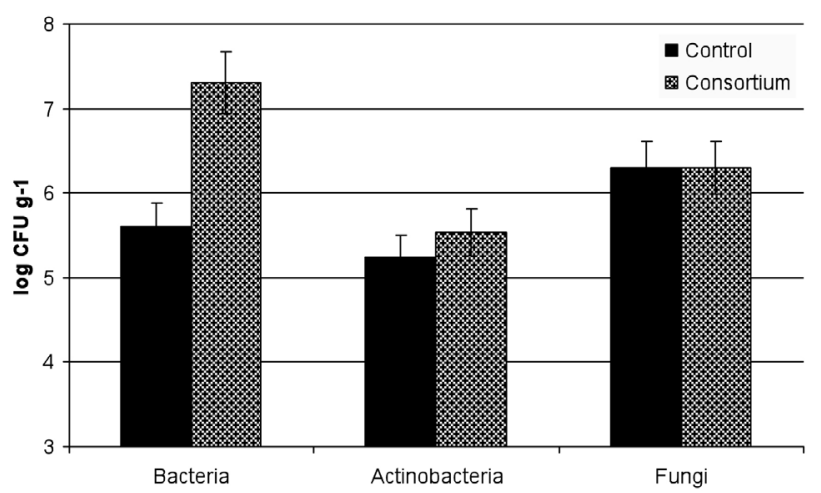

Fig. 4. Amount of CFU of microorganisms in the barley rhizosphere after 19 -day vegetation experiment. ${ }^{*}$, significant difference with control $(P<0.05)$.

plants and environmental damage (Smith et al. 2015).

The total number of cultivable bacteria in the rhizosphere of barley after the 19-day vegetation experiment varied from $5.6 \log \mathrm{CFU} \mathrm{g}^{-1}$ in the control to $7.3 \log \mathrm{CFU} \mathrm{g}^{-1}$ in the variant with the consortium $(P<0.05$, Fig. 4$)$. The presence of the consortium had no significant effect on the concentration of actinobacteria and fungi in barley rhizosphere. Colonies of cellulolytic and P solubilizing microorganisms were not found after the vegetation experiment.

Species participating in our biofertilizer consortium, such as Serratia liquefaciens (Kalbe et al. 1996) and Stenotrophomonas maltophilia (Berg et al. 1996), are known as beneficial rhizobacteria. Pseudomonas putida (Zawoznik et al. 2014) and most species of Serratia (Kalbe et al. 1996) secrete IAA, which can directly promote root growth. Several recent studies have demonstrated also beneficial effects for plants, shown by quorum sensing molecules, in particular the $\mathrm{N}$-acyl homoserine lactone group produced by different Gram-negative bacteria (reviewed in Schikora et al.2016) such as S. liquefaciens and P.putida (Schuhegger et al. 2006). Several Gram-positive bacteria like Bacillus and Brevibacillus species, including B. brevis, produce acyl-homoserine lactonase and are recognized as quorum quenching (Khoiri et al. 2017). B. brevis improves plant growth through combined modes of actions, including P solubilization and IAA production (Nehra et al. 2016). It cannot be excluded that some members of our multistrain consortium had opposite and conflicting effects. Interactions between species in multi-strain consortiums and between introduced and indigenous populations can be beneficial or detrimental.

A change in microorganism activity often leads to a change in soil microbial community composition (Leff et al. 2015). Increase of concentration of rhizosphere microorganisms is a possible reason for improvement of plant growth (Lehmann et al. 2011). In our study, a significant increase of bacterial CFU was found in soil after 19 days of bioaugmentation with the consortium. Kaiser et al. (2016) conducted analysis of 300 soil samples from three German regions and came to the conclusion that soil $\mathrm{pH}$ is the best predictor for bacterial community structure, diversity and function. Zhao et al. (2005) showed that biofertilizers containing plant growth promoting microorganisms influenced the diversity of fungal community by promoting development of cellulolytic fungi. In our study, concentration of $\mathrm{P}$ solubilizing and cellulolytic microorganisms in the rhizosphere at the end of the vegetation experiment was too low to be detected, even though particular components of the consortium were capable of solubilizing P. Molecular testing should be used in future to clarify the effect of the microbial consortium(s) on the composition of microbial communities in the rhizosphere.

\section{Acknowledgements}

This work was supported by the National Research Programme of Latvia "Sustainable Use of Forests and Mineral Deposits - New Products and Technologies (ResProd)" and project of University of Latvia "Climate Change and its Impacts on Sustainability of Natural Resources".

\section{References}

Ahmad F., Ahmad I., Khan M.S. 2008. Screening of free-living rhizospheric bacteria for their multiple plant growth promoting activities. Microbiol. Res. 163: 173-181.

American Public Health Association. 1992. Standard Methods for the Examination of Water and Wastewater. $18^{\text {th }}$ ed. APHA, Washington. $1100 \mathrm{p}$.

Berg G., Marten P., Ballin G. 1996. Stenotrophomonas maltophilia in the rhizosphere of oilseed rape - occurrence, characterization and interaction with phytopathogenic fungi. Microbiol. Res. 151: 19-27.

Bhardwaj D.,Ansari M.W.,Sahoo R.K., Tuteja N.2014. Biofertilizers function as key player in sustainable agriculture by improving soil fertility, plant tolerance and crop productivity. Microb. Cell Fact. 13: 66.

Bradford M.M. 1976. A rapid and sensitive method for the quantitation of microgram quantities of protein utilizing the principle of protein-dye binding. Anal. Biochem. 72: 248-254.

Burbank M.B., Weaver T.J., Williams B.C., Crawford R.L. 2012. Urease activity of ureolytic bacteria isolated from six soils in which calcite was precipitated by indigenous bacteria. Geomicrobiol. J. 29: 389-395.

Chen Y., Fan J.B., Du L., Xu H., Zhang Q.H., He Y.Q. 2014. The application of phosphate solubilizing endophyte Pantoea dispersa triggers the microbial community in red acidic soil. Appl. Soil Ecol. 84: 235-244.

Choi W.J., Chang S.X., Kwak J.H., Jung J.W., Lim S.S., Yoon K.S., Choi S.M. 2007. Nitrogen transformations and ammonia volatilization losses from ${ }^{15} \mathrm{~N}$-urea as affected by the coapplication of composted pig manure. Can. J. Soil Sci. 87: 485-493.

Collavino M.M., Sansberro P.A., Mroginski L.A., Aguilar O.M. 2010. Comparison of in vitro solubilisation activity of diverse phosphate-solubilizing bacteria native to acid soil and their ability to promote Phaseolus vulgaris growth. Biol. Fertil. Soils 46: $727-738$. 
Das S.K., Varma A. 2011. Role of enzymes in maintaining soil health. In: Shukla G., Varma A. (eds) Soil Enzymology. Soil Biology Vol. 22. Springer, Berlin, Heidelberg, pp. 25-42.

Gyaneshwar P., Kumar G.N., Parekh L.J., Poole P.S. 2002. Role of soil microorganisms in improving $\mathrm{P}$ nutrition of plants. Plant Soil 245: 83-93.

Hallmann J., Quadt-Hallmann A., Mahaffee W.F., Kloepper J.W. 1997. Bacterial endophytes in agricultural crops. Can. J. Microbiol. 43: 895-914.

He F., Zhang Z., Cui M., Xue Q. 2015. Effect of biocontrol actinomycetes agents on microflora in the root-zone of Amorphophallus konjac K. Koch ex N.E.Br. Chinese J. Appl. Environ. Biol. 21: 221-227.

Herrmann L., Lesueur D. 2013. Challenges of formulation and quality of biofertilizers for successful inoculation. Appl. Microbiol. Biotechnol. 97: 8859-8873.

Kaiser K., Wemheuer B., Korolkow V., Wemheuer F., Nacke H., Schöning I., Schrumpf M., Daniel R. 2016. Driving forces of soil bacterial community structure, diversity, and function in temperate grasslands and forests. Sci. Rep. 6: 33696.

Kalbe C., Marten P., Berg G. 1996. Strains of the genus Serratia as beneficial rhizobacteria of oilseed rape with antifungal properties. Microbiol. Res. 151: 433-439.

Kiffer E., Morelet M. 2000. The Deuteromycetes, Mitosporic Fungi: Classification and Generic Keys. Taylor \& Francis, Enfield. 273 p.

Khoiri S., Damayanti T.A., Giyanto G. 2017. Identification of quorum quenching bacteria and its biocontrol potential against soft rot disease bacteria, Dickeya dadantii. Agrivita J. Agric. Sci. 39: 45-55.

Leff J.W., Jones S.E., Prober S.M., Barberan A., Borer E.T., Firn J.L., Harpole W.S., Hobbie S.E., Hofmockel K.S., Knops J.M.H., McCulley R.L., Pierre K.L., Risch A.C., Seabloom E.W., Schütz M., Steenbock C., Stevens C.J., Fierer N. 2015. Consistent responses of soil microbial communities to elevated nutrient inputs in grasslands across the globe. Proc. Natl. Acad. Sci. USA 112: 10967-10972.

Lehmann J., Rillig M.C., Thies J., Masiello C.A., Hockaday W.C., Crowley D. 2011. Biochar effects on soil biota - a review. Soil Biol. Biochem. 43: 1812-1836.

Ma Y.Y., Li Y.L., Lai H.X., Guo Q., Xue Q.H. 2017. Effects of two strains of Streptomyces on root-zone microbes and nematodes for biocontrol of root-knot nematode disease in tomato. Appl. Soil Ecol. 112: 34-41.

Marimuthu S., Subbian P., Ramamoorthy V., Samiyappan R. 2002. Synergistic effect of combined application of Azospirillum and Pseudomonas fluorescens with inorganic fertilizers on root rot incidence and yield of cotton. J. Plant Dis. Protect. 109: 569577.

Márquez S.S., Bills G.F., Zabalgogeazcoa I. 2010. Endophytic mycobiota of leaves and roots of the grass Holcus lanatus. Fungal Divers. 41: 115-123.

Nadeem S.M., Naveed M., Ayyub M., Khan M.Y., Ahmad M., Zahir Z.A. 2016. Potential, limitations and future prospects of Pseudomonas spp. for sustainable agriculture and environment: a review. Soil Environ. 35: 106-145.

Nautiyal C.S. 1999. An efficient microbiological growth medium for screening phosphate solubilizing microorganisms. FEMS Microbiol. Lett. 170: 265-270.

Nehra V., Saharan B.S., Choudhary M. 2016. Evaluation of Brevibacillus brevis as a potential plant growth promoting rhizobacteria for cotton (Gossypium hirsutum) crop.
Springerplus 5: 948.

Oteino N., Lally R.D., Kiwanuka S., Lloyd A., Ryan D., Germaine K.J., Dowling D.N. 2015. Plant growth promotion induced by phosphate solubilizing endophytic Pseudomonas isolates. Front. Microbiol. 6: 745.

Probanza A., Garcia J.A.L., Palomino M.R., Ramos B., Manero F.J.G. 2002. Pinus pinea L. seedling growth and bacterial rhizosphere structure after inoculation with PGPR Bacillus (B. licheniformis CECT 5106 and B. pumilus CECT 5105). Appl. Soil Ecol. 20: 75-84.

Promwee A., Issarakraisila M., Intana W., Chamswarng C., Yenjit P. 2014. Phosphate solubilization and growth promotion of rubber tree (Hevea brasiliensis Muell. Arg.) by Trichoderma strains. J. Agr. Sci. 6: 8-20.

Qin S., Miao Q., Feng W.W., Wang Y., Zhu X., Xing K., Jiang J.H. 2015. Biodiversity and plant growth promoting traits of culturable endophytic actinobacteria associated with Jatropha curcas L. growing in Panxi dry-hot valley soil. Appl. Soil Ecol. 93: $1-130$.

Samira M., Mohammad R., Gholamreza G. 2011. Carboxymethylcellulase and filter-paperase activity of new strains isolated from Persian Gulf. Microbiol. J. 1: 8-16.

Sarlistyaningsih L., Sivasithamparam K., Setter T.L. 1996. The role of limited oxygen supply and soil microorganisms on germination and survival of lupin seeds (Lupinus angustifolius L. cv. Gungurru) in waterlogged soil. Austr. J. Exp. Agric. 36: 323-329.

Schikora A., Schenk S.T., Hartmann A. 2016. Beneficial effects of bacteria-plant communication based on quorum sensing molecules of the $\mathrm{N}$-acyl homoserine lactone group. Plant Mol. Biol. 90: 605-612.

Schuhegger R., Ihring A., Gantner S., Bahnweg G., Knappe C., Vogg G., Hutzler P., Schmid M., Van Breusegem F., Eberl L., Hartmann A., Langebartels C. 2006. Induction of systemic resistance in tomato by $\mathrm{N}$-acyl-L-homoserine lactoneproducing rhizosphere bacteria. Plant Cell Environ. 29: 909918.

Schulz B., Boyle C. 2006. What are endophytes? In: Schulz B., Boyle C., Sieber T. (eds) Microbial Root Endophytes. Springer, Berlin, pp. 1-14.

Smith P., Cotrufo M.F., Rumpel C., Paustian K., Kuikman P.J., Elliott J.A., McDowell R., Griffiths R.I., Asakawa S., Bustamante M., House J.I., Sobocká J., Harper R., Pan G., West P.C., Gerber J.S., Clark J.M., Adhya T., Scholes R.J., Scholes M.C. 2015. Biogeochemical cycles and biodiversity as key drivers of ecosystem services. Soil 1: 665-685.

Spagnoletti F.N., Tobar N.E., Di Pardo A.F., Chiocchio V.M., Lavado R.S. 2017. Dark septate endophytes present different potential to solubilize calcium, iron and aluminum phosphates. Appl. Soil Ecol. 111: 25-32.

Teather R.M., Wood P.J. 1982. Use of congo red-polysaccharide interactions in enumeration and characterization of cellulolytic bacteria from the bovine rumen. Appl. Environ. Microbiol. 43: 777-780.

Thompson D.P., Eribo B.E. 1984. Extracellular enzyme production by Rhizopus and Mucor species on solid media. Can. J. Microbiol. 30: 126-128.

Trabelsi D., Mhamdi R. 2013. Microbial inoculants and their impact on soil microbial communities: a review. BioMed. Res. Int. 2013: Article ID 863240.

Vecstaudza D., Senkovs M., Nikolajeva V., Kasparinskis R., Muter O. 2017. Wooden biochar as a carrier for endophytic isolates. 
Rhizosphere 3: 126-127.

Vyas P., Gulati A. 2009. Organic acid production in vitro and plant growth promotion in maize under controlled environment by phosphate-solubilizing fluorescent Pseudomonas. BMC Microbiol. 9: 174.

Wang J., Song Y., Ma T., Raza W., Li J., Howland J.G., Huang Q., Shen Q. 2017. Impacts of inorganic and organic fertilization treatments on bacterial and fungal communities in a paddy soil. Appl. Soil Ecol. 112: 42-50.

Weise T., Kai M., Piechulla B. 2013. Bacterial ammonia causes significant plant growth inhibition. PLoS One 8: e63538.

Wemheuer F., Kaiser K., Karlovsky P., Daniel R., Vidal S., Wemheuer B.2017. Bacterial endophyte communities of three agricultural important grass species differ in their response towards management regimes. Sci. Rep. 7: 40914.

Zawoznik M.S., Vázquez S.C., Díaz Herrera S.M., Groppa M.D. 2014. Search for endophytic diazotrophs in barley seeds. Braz. J. Microbiol. 45: 621-625.

Zhao Y., Li W., Zhou Z., Wang L., Pan Y., Zhao L. 2005. Dynamics of microbial community structure and cellulolytic activity in agricultural soil amended with two biofertilizers. Eur. J. Soil Biol. 41: 21-29.

Zinniel D.K., Lambrecht P., Harris N.B., Feng Z., Kuczmarski D., Higley P., Ishimaru C.A., Arunakumari A., Barletta R., Vidaver A.K. 2002. Isolation and characterization of endophytic colonizing bacteria from agronomic crops and prarie plants. Appl. Environ. Microbiol. 68: 2198-2208. 